\title{
The tropical caprellid amphipod Paracaprella pusilla: a new alien crustacean in the Mediterranean Sea
}

\author{
Macarena Ros • Maite Vázquez-Luis • \\ José Manuel Guerra-García
}

Received: 10 January 2013/Revised: 19 March 2013/Accepted: 25 March 2013/Published online: 9 April 2013

(C) Springer-Verlag Berlin Heidelberg and AWI 2013

\begin{abstract}
Paracaprella pusilla Mayer (Fauna und Flora des Golfes von Neapel 17:1-55, 1890), originally described from Brazil, is one of the most abundant caprellid amphipod species in tropical and subtropical seas around the world. During a survey of caprellid amphipods from marinas along the Balearic Island (Western Mediterranean Sea) carried out between November 2011 and August 2012, we found two established populations of $P$. pusilla in Mallorca and Ibiza, respectively. So far, its occurrence in European waters was reported only from southwestern Spain in 2010. This record represents a northward range expansion of the species' distribution, which is found for the first time in the Mediterranean. This is also the first record of the genus Paracaprella in the Mediterranean Sea. The most probable introduction vector was ship fouling. We also found the invasive caprellid Caprella scaura Templeton (Trans Entomol Soc Lond 1:185-198, 1836) in Mallorca and Menorca, which is recorded for the first time in the Balearic Islands, confirming its rapid expansion along the Mediterranean. When comparing reproductive traits between both alien species, we found that $P$. pusilla has a higher fecundity than $C$. scaura for the same female size. Taking into account this evidence, the species may be
\end{abstract}

Communicated by H.-D. Franke.

M. Ros $(\bowtie) \cdot$ J. M. Guerra-García

Laboratorio de Biología Marina, Dpto. Zoología, Facultad de

Biología, Universidad de Sevilla, Avda Reina Mercedes 6,

41012 Sevilla, Spain

e-mail:mros@us.es

M. Vázquez-Luis

I.E.O., Centre Oceanogràtic de les Balears,

Moll de Ponent s/n, 07015 Palma de Mallorca, Spain expected to appear in other Mediterranean and adjacent areas.

Keywords Invasive species - Aquatic invasions - First record $\cdot$ Ship fouling $\cdot$ Secondary spread $\cdot$ Fouling communities

\section{Introduction}

The Mediterranean Sea is one of the world areas most affected by biological invasions with about 955 introduced species, 153 of these representing crustaceans (Zenetos et al. 2010). Among alien crustaceans, the taxa most frequently recorded in the Mediterranean are Decapoda, followed by Calanoida and Amphipoda (Galil 2011). However, although the number of alien crustaceans has increased noticeably in the last two decades, probably reflecting both an increase in introductions and an interest in their study (Galil 2009), the number of alien crustaceans in the groups of amphipods, cirripedes, cumaceans, isopods and tanaidaceans is still underestimated (Zenetos et al. 2010). Caprellid amphipods, commonly known as skeleton shrimps, are small marine crustaceans that are common in many littoral habitats, where they form an important trophic link between primary producers and higher trophic levels (Woods 2009). The morphology of caprellids, with reduced abdominal appendages which in other amphipods are used for swimming (Takeuchi and Sawamoto 1998) as well as a lack of a planktonic larval stage, suggests that the cosmopolitan distribution of many littoral caprellids is facilitated by the fact that they are often associated with fouling communities on floating objects and vessels (Thiel et al. 2003). 
The Mediterranean Sea has one of the best-documented amphipod faunas in the world (Ruffo 1982, 1989, 1993, 1998), but new species are still being described, especially in the case of caprellid amphipods (e.g. Caprella tavolarensis Sturaro and Guerra-García 2011, based on specimens collected from Posidonia oceanica), indicating that further sampling should be conducted to complete our knowledge about Mediterranean caprellids. This is particularly important in the case of fouling communities in harbours and marinas which are still scarcely sampled in some areas of the Mediterranean. Fouling communities include arborescent substrates such as bryozoans and hydroids, which may act as suitable reservoirs for introduced caprellids that have remained unrecorded as yet (Ros et al. 2013). Bellan-Santini and Ruffo (1998) list three caprellid species native to the Mediterranean but known for their propensity for passive dispersal and presence in Mediterranean harbour fouling communities: Caprella acanthifera, C. dilatata and C. equilibra. In 1994, an unusual-looking caprellid, characterized by an acute cephalic projection, was found associated with the fouling community of the wooden piles in the Lagoon of Venice (Sacchi et al. 1998). This caprellid, identified later as Caprella scaura (Templeton 1836) by Sandro Ruffo (Krapp et al. 2006), represented the first and only introduced caprellid reported in the Mediterranean Sea. During the last decade, this Indopacific species has spread very fast across the Mediterranean Sea and has expanded its non-native range to the East Atlantic coast (Sconfietti et al. 2005; Krapp et al. 2006; Galil 2008; Martínez and Adarraga 2008; Ben Souissi et al. 2010; Bakir and Katagan 2011; Guerra-García et al. 2011a; Eleftheriou et al. 2011). In September 2010, an established population of another alien caprellid, the tropical species Paracaprella pusilla Mayer 1890, was found for the first time in European waters, in the fouling community of a marina on the southwest Atlantic coast of Spain (Ros and GuerraGarcía 2012). This tropical/subtropical species, originally described from Rio de Janeiro, Brazil, by Mayer (1890), was found associated with the native hydroid Eudendrium racemosum.

This study reports the result of a survey on the fouling communities of marinas of the Balearic Islands to determine the presence and quantify abundances of non-indigenous caprellids (NICs) in the Western Mediterranean region. Considering our scant knowledge about the ecology of $P$. pusilla, some reproductive biology traits were studied for the first time for the species, and its fecundity was compared with the invasive $C$. scaura. The likely vector and pattern of introduction of $P$. pusilla in the Mediterranean Sea as well as the species' current status were analyzed.

\section{Materials and methods}

Study area

The Balearic Islands, located in the centre of the Western Mediterranean, are one of the most important tourist destinations in the Mediterranean Sea and are among the preferred destinations for cruise ships crossing the Mediterranean (Minchin et al. 2006). They are characterised by an intense maritime traffic and are a potential hot spot of marine biological invasions (see Drake and Lodge 2004). The region comprises the four main islands of Mallorca, Menorca, Ibiza and Formentera, as well as the small island of Cabrera (Fig. 1).

\section{Sampling}

The sampling programme was conducted between November 2011 and August 2012. A total of 20 recreational marinas along the coast of the Balearic Islands were sampled to ensure a complete review of the total fouling communities which proliferate on artificial hard substrate including pilings, floating pontoons, ropes, buoys, wheels and ship hulls (Table 1). When caprellids were detected in a type of fouling substrate (hydroids, bryozoans or macroalgae), three random replicates of each substrate were taken by hand and fixed in situ in $90 \%$ ethanol. Environmental parameters (water temperature, salinity and turbidity) were measured in situ at each sampling station. Three haphazard measurements were made for each parameter across the floating pontoon system, and mean values and standard deviations were calculated. Salinity and temperature were measured using a conductivity meter CRISON MM40 and turbidity in nephelometric turbidy units (ntu) using a turbidimeter WTW 335 IR.

Laboratory processing and statistical analysis

All caprellids were sorted and identified to species level. Abundance of caprellids was expressed as number of individuals $/ 1,000 \mathrm{ml}$ of substrate because of the different structure of the substrate types (see Pereira et al. 2006; Guerra-García et al. 2011b). Volume of substrates was estimated as the difference between the initial and final volume when placed into a graduated cylinder with a fixed amount of water. Subsequently, all non-native caprellids collected were photographed on a stereomicroscope Motic K-400L with a Nikon D90 digital camera. Body length of males, mature females (with the brood pouch fully developed) and premature females (with the brood pouch underdeveloped) was measured from the front of the head to the end of pereonite 7, using the PC-based digitizing software Scion Image Alpha 4.0.3.2 (C) (2000-2001 Scion 
Fig. 1 Map of the Balearic Islands showing sampling stations and presence/absence of NICs (non-indigenous caprellids). See also Table 1

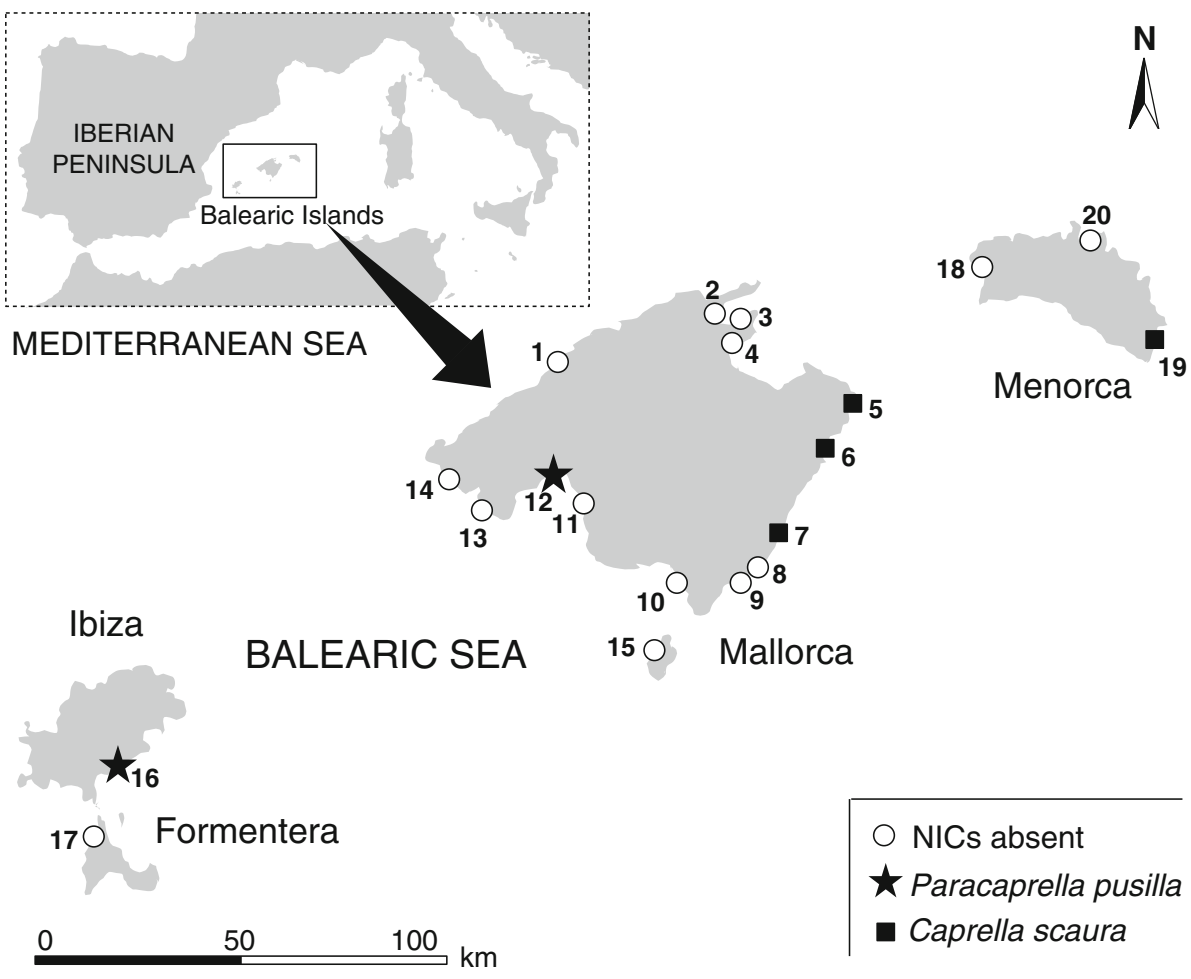

Corporation). A total of 145 individuals of $C$. scaura and 106 of $P$. pusilla were measured. For each non-native caprellid species found, eggs from 15 ovigerous females with the brood pouch completely closed were counted by removing them from the brood pouch with a dissecting needle. To test possible relationships between female size and number of eggs, Pearson's correlation coefficient was calculated for each species, and differences between the slopes of regression lines of both species were tested using parallelism and equality of lines tests.

\section{Reproductive traits}

Five reproductive traits were selected to compare the fecundity of alien species found in the present study (modified after Grabowski et al. 2007): (a) mean size of ovigerous females, (b) brood size (mean number of eggs per brood pouch), (c) maximum number of eggs, (d) partial fecundity index (mean brood size/mean size of ovigerous females) and (e) relative age at reaching maturity (minimal size/mean size of ovigerous females). The comparisons were carried out with alien caprellids from the same region (Mallorca) and collected in the same season (November 2011) to avoid confounding factors.

\section{Results}

Two non-native caprellids were found in the Balearic Islands, Paracaprella pusilla and Caprella scaura. The morphological characteristics used to define $P$. pusilla are (1) the large anterolateral projection of pereonite 2, (2) small dorsal tubercle on pereonite 2, (3) proximal knob on the basis of gnathopod 2 and (4) lateral pleura in pereonites 3 and 4, especially developed in pereonite 3 (see plate 2, Figs 36 and 37 in Mayer (1903)). Individuals collected in Mallorca and Ibiza display these features (Fig. 2). Drawings of $P$. pusilla from different world areas (Guerra-García 2006 from Colombia, Guerra-García et al. 2010 from India and Díaz et al. 2005 from Venezuela) and our own examination of specimens from the Gulf of Mexico, Brazil, India, Southern Spain and the Balearic Islands showed little intraspecific variation in morphology. The morphological characteristics used to identify C. scaura from the Mediterranean are (1) cephalon with an acute, bent forward, dorsal projection, (2) pereonites 1 and 2 elongate in males, (3) basis of gnathopod 2 long but shorter than pereonite 2 and (4) absence of ventral projection between the insertion of gnathopods 2 (Templeton 1836; Mayer 1890; Krapp et al. 2006). Individuals collected in Mallorca and Menorca display these features and are similar to other populations from the Iberian Peninsula, the Canary Islands, Italy and Greece, which were examined by the authors. Both alien species are easily differentiated from native species common in fouling communities (Ros et al. 2013).

Alien caprellids were present in the three islands of Mallorca, Menorca and Ibiza and were absent from the islands of Formentera and Cabrera (Fig. 1). Paracaprella 
Table 1 Locations and environmental characteristics of marinas surveyed in the present study

\begin{tabular}{|c|c|c|c|c|c|c|c|c|c|}
\hline Island & & Marina & Locality & Coordinates & Date & $\begin{array}{l}\text { Temperature }{ }^{\circ} \mathrm{C} \\
(\text { mean } \pm \mathrm{SD})\end{array}$ & $\begin{array}{l}\text { Salinity } \\
(\text { mean } \pm \mathrm{SD})\end{array}$ & $\begin{array}{l}\text { Turbidity (ntu) } \\
\text { (mean } \pm \text { SD) }\end{array}$ & $\begin{array}{l}\text { NICs } \\
\text { present }\end{array}$ \\
\hline \multirow[t]{14}{*}{ MALLORCA } & 1 & Puerto de Sóller & Sóller & $\begin{array}{r}39^{\circ} 47^{\prime} \mathrm{N} \\
2^{\circ} 41^{\prime} \mathrm{E}\end{array}$ & $\begin{array}{r}6 \mathrm{Nov} \\
2011\end{array}$ & $17.7 \pm 0.1$ & $23.8 \pm 0.2$ & $18.1 \pm 4.9$ & - \\
\hline & 2 & $\begin{array}{l}\text { Puerto de } \\
\text { Pollença }\end{array}$ & Pollença & $\begin{array}{r}39^{\circ} 54^{\prime} \mathrm{N} \\
3^{\circ} 0.5^{\prime} \mathrm{E}\end{array}$ & $\begin{array}{r}5 \mathrm{Nov} \\
2011\end{array}$ & $20.3 \pm 0.1$ & $37.9 \pm 0.0$ & $5.8 \pm 0.7$ & - \\
\hline & 3 & Es Barcarés & Alcúdia & $\begin{array}{r}39^{\circ} 52^{\prime} \mathrm{N} \\
3^{\circ} 0.5^{\prime} \mathrm{E}\end{array}$ & $\begin{array}{l}12 \mathrm{Mar} \\
2012\end{array}$ & $17.1 \pm 0.3$ & $37.3 \pm 0.1$ & $1.3 \pm 0.2$ & - \\
\hline & 4 & Alcudiamar & Alcúdia & $\begin{array}{r}39^{\circ} 49^{\prime} \mathrm{N} \\
3^{\circ} 0.8^{\prime} \mathrm{E}\end{array}$ & $\begin{array}{r}5 \mathrm{Nov} \\
2011\end{array}$ & $19.4 \pm 0.2$ & $35.3 \pm 0.5$ & $7.4 \pm 5.1$ & - \\
\hline & 5 & $\begin{array}{l}\text { Club Náutico } \\
\text { Cala Ratjada }\end{array}$ & $\begin{array}{l}\text { Cala } \\
\text { Ratjada }\end{array}$ & $\begin{array}{r}39^{\circ} 43^{\prime} \mathrm{N} \\
3^{\circ} 28^{\prime} \mathrm{E}\end{array}$ & $\begin{array}{r}5 \mathrm{Nov} \\
2011\end{array}$ & $21.6 \pm 0.5$ & $37.5 \pm 0.0$ & $10.6 \pm 2.7$ & Cs \\
\hline & 6 & $\begin{array}{l}\text { Puerto de Cala } \\
\text { Bona }\end{array}$ & Cala Bona & $\begin{array}{r}39^{\circ} 37^{\prime} \mathrm{N} \\
3^{\circ} 23^{\prime} \mathrm{E}\end{array}$ & $\begin{array}{r}6 \mathrm{Nov} \\
2011\end{array}$ & $19.9 \pm 0.1$ & $36.0 \pm 0.1$ & $7.6 \pm 1.7$ & $\mathrm{Cs}$ \\
\hline & 7 & $\begin{array}{l}\text { Club Náutico } \\
\text { Porto Colom }\end{array}$ & $\begin{array}{l}\text { Porto } \\
\text { Colom }\end{array}$ & $\begin{array}{c}39^{\circ} 25^{\prime} \mathrm{N} \\
3^{\circ} 15^{\prime} \mathrm{E}\end{array}$ & $\begin{array}{r}6 \mathrm{Nov} \\
2011\end{array}$ & $16.3 \pm 0.1$ & $37.6 \pm 0.3$ & $36.3 \pm 3.6$ & Cs \\
\hline & 8 & $\begin{array}{l}\text { Marina de Cala } \\
\text { d'Or }^{\prime}\end{array}$ & Cala d'Or & $\begin{array}{r}39^{\circ} 22^{\prime} \mathrm{N} \\
3^{\circ} 14^{\prime} \mathrm{E}\end{array}$ & $\begin{array}{r}6 \mathrm{Nov} \\
2011\end{array}$ & $20.3 \pm 0.1$ & $37.5 \pm 0.5$ & $4.7 \pm 1.0$ & - \\
\hline & 9 & $\begin{array}{l}\text { Puerto de Porto } \\
\text { Petro }\end{array}$ & Santanyí & $\begin{array}{r}29^{\circ} 21^{\prime} \mathrm{N} \\
3^{\circ} 12^{\prime} \mathrm{E}\end{array}$ & $\begin{array}{r}6 \mathrm{Nov} \\
2011\end{array}$ & $19.8 \pm 0.1$ & $37.6 \pm 0.3$ & $12.7 \pm 6.0$ & - \\
\hline & 10 & $\begin{array}{l}\text { Puerto Colònia } \\
\text { Sant Jordi }\end{array}$ & $\begin{array}{l}\text { Colònia } \\
\text { Sant } \\
\text { Jordi }\end{array}$ & $\begin{array}{r}39^{\circ} 18^{\prime} \mathrm{N} \\
2^{\circ} 59^{\prime} \mathrm{E}\end{array}$ & $\begin{array}{r}6 \mathrm{Nov} \\
2011\end{array}$ & $18.8 \pm 0.1$ & $35.0 \pm 0.1$ & $58.0 \pm 22.4$ & - \\
\hline & 11 & $\begin{array}{l}\text { Club Náutico El } \\
\text { Arenal }\end{array}$ & El Arenal & $\begin{array}{r}39^{\circ} 30^{\prime} \mathrm{N} \\
3^{\circ} 45^{\prime} \mathrm{E}\end{array}$ & $\begin{array}{c}11 \text { Nov } \\
2011\end{array}$ & $16.9 \pm 0.1$ & $37.2 \pm 0.1$ & $1.9 \pm 0.4$ & - \\
\hline & 12 & Puerto de Palma & $\begin{array}{l}\text { Palma de } \\
\text { Mallorca }\end{array}$ & $\begin{array}{r}39^{\circ} 34^{\prime} \mathrm{N} \\
2^{\circ} 38^{\prime} \mathrm{E}\end{array}$ & $\begin{array}{r}5 \mathrm{Nov} \\
2011\end{array}$ & $21.5 \pm 0.1$ & $33.4 \pm 1.3$ & $3.8 \pm 1.3$ & $\mathrm{Pp}$ \\
\hline & 13 & Puerto Adriano & El Toro & $\begin{array}{r}39^{\circ} 29^{\prime} \mathrm{N} \\
2^{\circ} 29^{\prime} \mathrm{E}\end{array}$ & $\begin{array}{r}7 \mathrm{Nov} \\
2011\end{array}$ & $20.3 \pm 0.1$ & $36.0 \pm 0.1$ & $5.3 \pm 1.0$ & - \\
\hline & 14 & $\begin{array}{l}\text { Club de Vela } \\
\text { Puerto de } \\
\text { Andratx }\end{array}$ & Andratx & $\begin{array}{r}39^{\circ} 33^{\prime} \mathrm{N} \\
2^{\circ} 24^{\prime} \mathrm{E}\end{array}$ & $\begin{array}{r}7 \mathrm{Nov} \\
2011\end{array}$ & $19.9 \pm 0.1$ & $37.7 \pm 0.3$ & $10.7 \pm 0.1$ & - \\
\hline CABRERA & 15 & Puerto de Cabrera & Cabrera & $\begin{array}{c}39^{\circ} 0.9^{\prime} \mathrm{N} \\
2^{\circ} 59^{\prime} \mathrm{E}\end{array}$ & $\begin{array}{c}30 \mathrm{Abr} \\
2012\end{array}$ & - & - & - & - \\
\hline IBIZA & 16 & $\begin{array}{l}\text { Club náutico de } \\
\text { Ibiza }\end{array}$ & Ibiza & $\begin{array}{r}38^{\circ} 54^{\prime} \mathrm{N} \\
1^{\circ} 26^{\prime} \mathrm{E}\end{array}$ & $\begin{array}{l}2 \text { Jun } \\
2012\end{array}$ & $20.5 \pm 0.5$ & $35.3 \pm 0.5$ & $2.2 \pm 0.2$ & $\mathrm{Pp}$ \\
\hline FORMENTERA & 17 & $\begin{array}{l}\text { Puerto de La } \\
\text { Savina }\end{array}$ & La Savina & $\begin{array}{r}38^{\circ} 44^{\prime} \mathrm{N} \\
1^{\circ} 25^{\prime} \mathrm{E}\end{array}$ & $\begin{array}{l}2 \text { Jun } \\
2012\end{array}$ & $20.5 \pm 0.5$ & $35.3 \pm 0.5$ & $1.4 \pm 0.2$ & - \\
\hline \multirow[t]{3}{*}{ MENORCA } & 18 & $\begin{array}{l}\text { Club náutico de } \\
\text { Ciutadella }\end{array}$ & Ciutadella & $\begin{array}{r}39^{\circ} 58^{\prime} \mathrm{N} \\
3^{\circ} 49^{\prime} \mathrm{E}\end{array}$ & $\begin{array}{r}19 \mathrm{Jul} \\
2012\end{array}$ & $25.6 \pm 0.1$ & $36.0 \pm 0.4$ & $1.3 \pm 0.4$ & - \\
\hline & 19 & $\begin{array}{l}\text { Club marítimo de } \\
\text { Mahón }\end{array}$ & Mahón & $\begin{array}{r}39^{\circ} 52^{\prime} \mathrm{N} \\
4^{\circ} 18^{\prime} \mathrm{E}\end{array}$ & $\begin{array}{r}20 \mathrm{Jul} \\
2012\end{array}$ & $26.3 \pm 0.0$ & $37.1 \pm 0.2$ & $1.7 \pm 0.8$ & Cs \\
\hline & 20 & Puerto de Fornells & Mahón & $\begin{array}{r}40^{\circ} 03^{\prime} \mathrm{N} \\
4^{\circ} 0.8^{\prime} \mathrm{E}\end{array}$ & $\begin{array}{l}19 \text { Aug } \\
2012\end{array}$ & - & - & - & - \\
\hline
\end{tabular}

Cs Caprella scaura, Pp Paracaprella pusilla, NICs Non-indigenous caprellids, SD standard deviation

pusilla was found in Palma marina (Mallorca; $39^{\circ} 34^{\prime} \mathrm{N}$, $2^{\circ} 38^{\prime} \mathrm{E}$ ) and Ibiza marina (Ibiza; $\left.38^{\circ} 54^{\prime} \mathrm{N}, 1^{\circ} 26^{\prime} \mathrm{E}\right)$. The species was found in a water temperature range from $20.5{ }^{\circ} \mathrm{C}$ (Ibiza) to 21.5 (Mallorca), a salinity range from 33.4 (Mallorca) to 35.3 (Ibiza) and a turbidity range from $2.2 \mathrm{ntu}$ (Ibiza) to $3.8 \mathrm{ntu}$ (Mallorca) (Table 1). In both marinas, $P$. pusilla was found associated with the hydroid Eudendrium racemosum where it exhibited similar densities $(4,611 \pm 2,204 \mathrm{ind} / 1,000 \mathrm{ml}$ in Mallorca and $4,100 \pm 2,055$ ind $/ 1,000 \mathrm{ml}$ in Ibiza, Mean \pm Standard Error). In Palma marina (Mallorca), the species was also found with the hydroid Pennaria disticha (Table 2). The 
Fig. 2 a Lateral view of an adult male and an adult female of Paracaprella pusilla collected from Spain; $\mathbf{b}$ detail of the lateral pleura in pereonite 3 (see arrow) of an adult male; c detail of the anterior part of an adult male showing the small dorsal tubercle, the large anterolateral projection of pereonite 2 and the proximal knob on the basis of gnathopod 2 (see arrows); d detail of the gnathopod 2 of an adult male
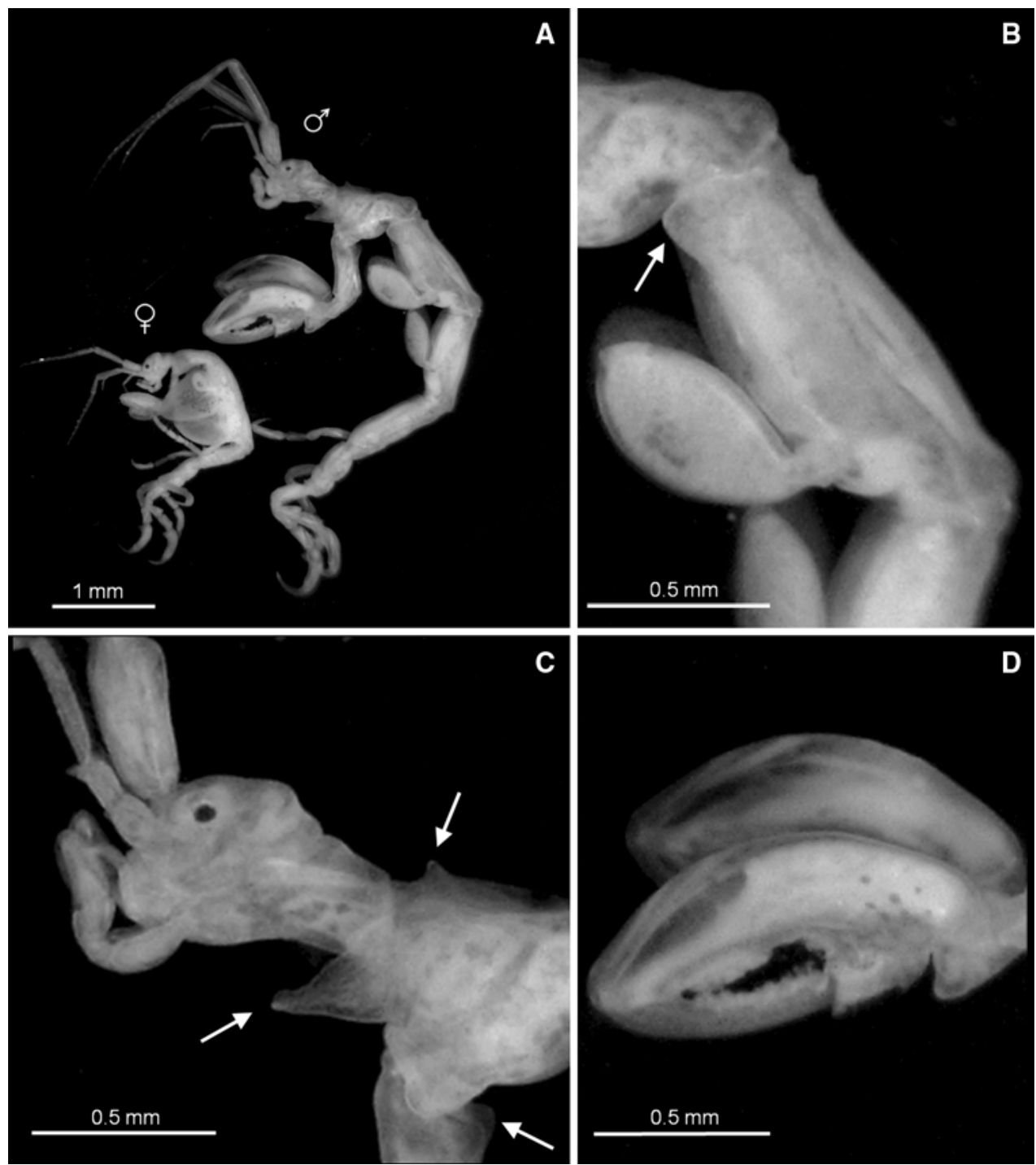

maximum total length recorded for males was $8.2 \mathrm{~mm}$, whereas for females, the maximum was $5.6 \mathrm{~mm}$ (Fig. 3). Caprella scaura was found in three marinas located in the northeast coast of Mallorca: Cala Ratjada $\left(39^{\circ} 43^{\prime} \mathrm{N}\right.$, $\left.3^{\circ} 28^{\prime} \mathrm{E}\right)$, Cala Bona $\left(39^{\circ} 37^{\prime} \mathrm{N}, 3^{\circ} 23^{\prime} \mathrm{E}\right)$ and Porto Colom $\left(39^{\circ} 25^{\prime} \mathrm{N}, 3^{\circ} 15^{\prime} \mathrm{E}\right)$ and in one marina in Menorca (Mahón; $\left.39^{\circ} 52^{\prime} \mathrm{N}, 4^{\circ} 18^{\prime} \mathrm{E}\right)$. The species was found in a water temperature range from $16.3{ }^{\circ} \mathrm{C}$ (Porto Colom, Mallorca) to $26.3{ }^{\circ} \mathrm{C}$ (Menorca), a salinity range from 36.0 (Cala Bona, Mallorca) to 37.6 (Porto Colom, Mallorca) and a turbidity range from $1.7 \mathrm{ntu}$ (Menorca) to $36.3 \mathrm{ntu}$ (Porto Colom, Mallorca) (Table 1). Caprella scaura was associated with eight different substrates, including hydroids, bryozoans and macroalgae of the marinas' fouling community (Table 2). The highest abundance was found in Cala Ratjada, associated with the bryozoan Bugula neritina $(18,333 \pm 8,647 \mathrm{ind} / 1,000 \mathrm{ml})$. The maximum total length recorded for males was $13.2 \mathrm{~mm}$, whereas for females, the maximum was $7.9 \mathrm{~mm}$ (Fig. 3). The large individuals of both sexes were found associated with bryozoans.

Regarding the reproductive traits, we found that the mean number of eggs per female was 29.07 for $P$. pusilla and 26.67 for C. scaura (Table 3). The partial fecundity index was 7.20 for $P$. pusilla and 5.32 for C. scaura, and the maturity index was 0.66 and 0.73 for $P$. pusilla and $C$. scaura, respectively. A significant correlation was found between female size and number of eggs for both species ( $P$. pusilla: $r=0.62, p<0.05$; C. scaura: $r=0.96, p<0.01$ ) (Fig. 4). Although the parallelism test did not show differences between the slopes of regression lines of the two species $\left(F_{1,26}=\right.$ $0.006, p=0.94)$, the equality of lines test showed significant differences between $C$. scaura and $P$. pusilla $\left(F_{2,26}=10.89, p=0.0004\right)$. The graph shows that for a given body size, females of $P$. pusilla had a higher number of eggs than females of $C$. scaura. 
Table 2 Density of non-indigenous caprellids (C. scaura and P. pusilla) found on different fouling species and in different locations of the Balearic Islands

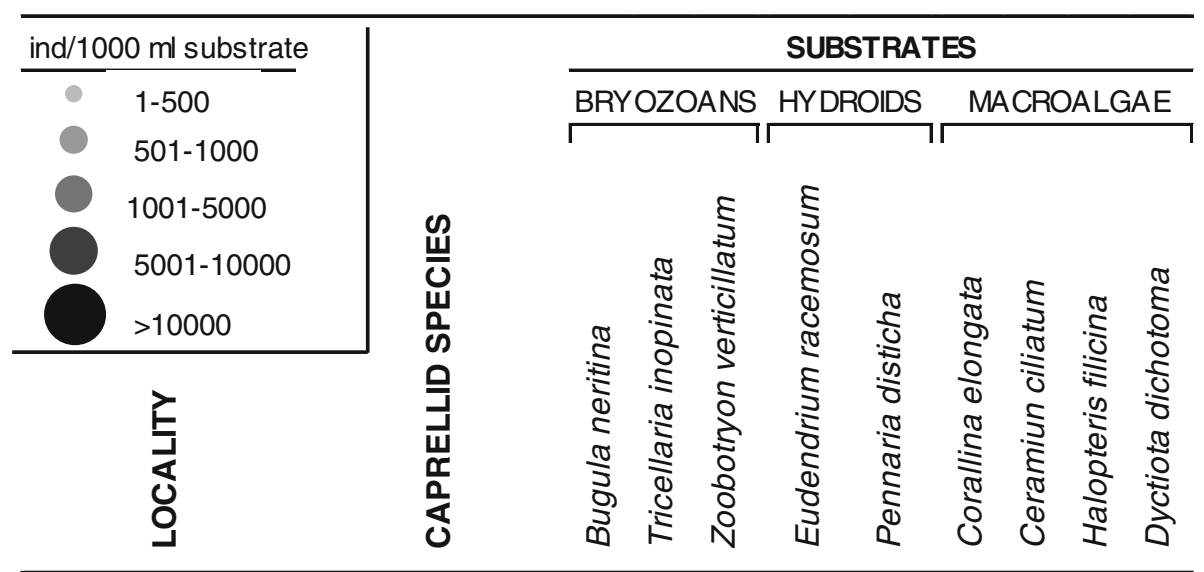

\begin{tabular}{|ll|}
\hline MALLORCA & \\
5. Portocolom & C. scaura \\
6. Cala Bona & C. scaura \\
7. Cala Ratjada & C. scaura \\
12. Palma & P. pusilla
\end{tabular}

IBIZA

16. Ibiza

P. pusilla

\section{MENORCA}

19. Mahón

C.scaura

\section{Discussion}

Non-native caprellids from the Balearic Islands and possible vectors of their introduction

We recorded, for the first time, the presence of the invasive C. scaura at the Balearic Islands as well as the presence of the introduced $P$. pusilla in the Mediterranean Sea, which represents the first record of the genus Paracaprella in the Mediterranean. These species were present at the islands of Mallorca, Menorca and Ibiza but were absent from the small islands of Formentera and Cabrera. Caprella scaura was found associated with a wide variety of fouling substrates, including macroalgae, hydroids and bryozoans, thus showing a high plasticity to colonize different habitat structures, while $P$. pusilla was only found associated with fouling hydroids. This pattern of habitat use was also found for both species in the fouling community of a marina in southern Spain (Ros et al. 2013) where P. pusilla was positively correlated with the native hydroid E. racemosum (Ros and Guerra-García 2012), reflecting a clear preference for hydroids in the non-native area. Although Caprella species have been found to survive transport in ballast tanks (Carlton 1985), for a fouling species frequently recorded from ports, transport via hull fouling is assumed to be the most probable vector (Galil 2011). As both P. pusilla and C. scaura were found associated with the fouling communities adherent to artificial hard substrates including ship hulls, ship fouling is assumed to be the most probable vector for the introduction of the species to the Balearic Islands. This may be related to the absence of both species from the islands of Formentera and Cabrera which have only few ports ( 2 and 1, respectively; FEAPDT 2011) and are therefore exposed to much lower boating pressure than the islands of Mallorca (39 ports), Menorca (9 ports) and Ibiza (8 ports).

\section{Reproductive traits}

Reproduction appears to be a major factor in the success of invasive amphipods (Weis 2010). Grabowski et al. (2007) studied six reproductive and two additional traits (salinity tolerance and tolerance to human impacts) to compare six invasive versus seven native gammarid species occurring in Central European waters. They found that invasive 
Fig. 3 Box-and-Whisker plot for each sex/age group measured for the different populations. Median values are included; the rectangles contain values between the first and the third quartiles; the bars connect the extreme values

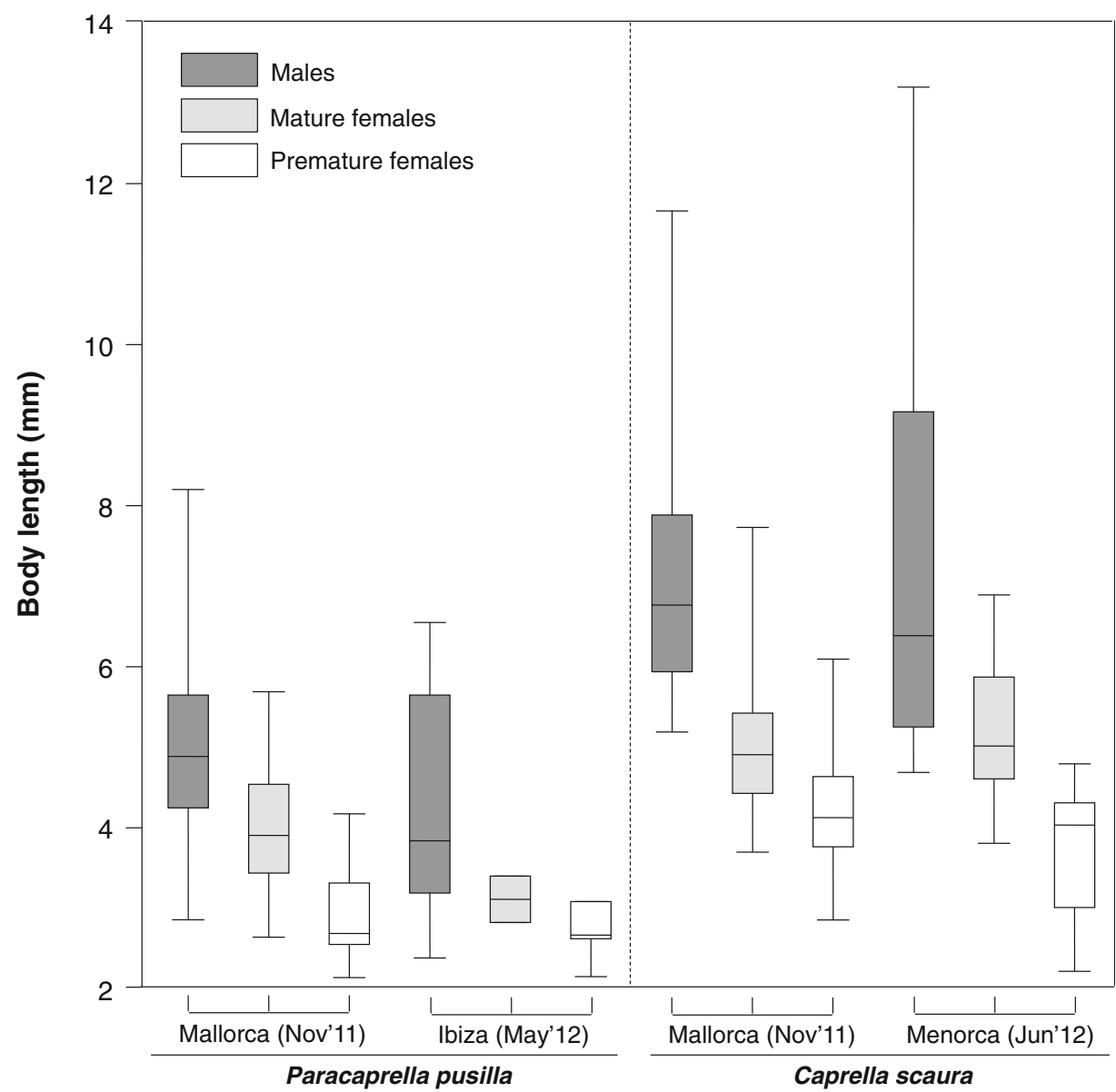

Table 3 Reproductive traits for non-indigenous caprellid populations collected at Mallorca in November 2011

\begin{tabular}{llllll}
\hline Species & $\begin{array}{l}\text { Mean ovigerous } \\
\text { female size } \\
(\mathrm{mm}) \pm \mathrm{SE}\end{array}$ & $\begin{array}{l}\text { Mean brood } \\
\text { size (no. eggs/female) } \\
\pm \mathrm{SE}\end{array}$ & $\begin{array}{l}\text { Maximum no. } \\
\text { eggs (female size) }\end{array}$ & $\begin{array}{l}\text { Partial fecundity } \\
\text { index (brood size/mean } \\
\text { female size) }\end{array}$ & $\begin{array}{l}\text { Maturity index } \\
\text { (min/mean } \\
\text { female size) }\end{array}$ \\
\hline P. pusilla & $4.62 \pm 0.14$ & $29.07 \pm 3.98$ & $62(5.40 \mathrm{~mm})$ & 7.20 & 0.66 \\
C. scaura & $5.59 \pm 0.32$ & $26.67 \pm 5.88$ & $72(7.30 \mathrm{~mm})$ & 5.32 & 0.73 \\
\hline
\end{tabular}

$S E$ standard error

gammarids were characterized by a combination of large brood size, high partial fecundity, early maturation and by the appearance of higher number of generations per year. In the present paper, we studied four of the six reproductive traits and an additional one (maximum number of eggs) in the newly introduced $P$. pusilla and C. scaura, an invasive species which has been spreading very fast across the Mediterranean and the East Atlantic coast (Guerra-García et al. 2011a). We found that $C$. scaura and $P$. pusilla females produce a larger mean number of eggs when compared with native species from the Mediterranean Sea with similar female size such as $C$. grandimana, with an average brood size of 7.6 eggs (Baeza-Rojano et al. 2011). When comparing $P$. pusilla with $C$. scaura, we found that $P$. pusilla produces more eggs per brood than $C$. scaura and has a higher partial fecundity index. This implies that for a given size of the female, $P$. pusilla has a higher number of eggs than $C$. scaura. However, as females of $C$. scaura can attain larger body sizes, the maximum number of eggs per female was higher in this species. Moreover, the maturity index and thus the relative age at reaching maturity are less in $P$. pusilla than in $C$. scaura. These traits may facilitate the secondary spread of the $P$. pusilla to new areas of the Mediterranean as has already happened with $C$. scaura.

\section{Current status of $P$. pusilla}

Similar to other alien caprellids in Europe such as Caprella mutica in Scotland (Willis et al. 2004), the non-indigenous 


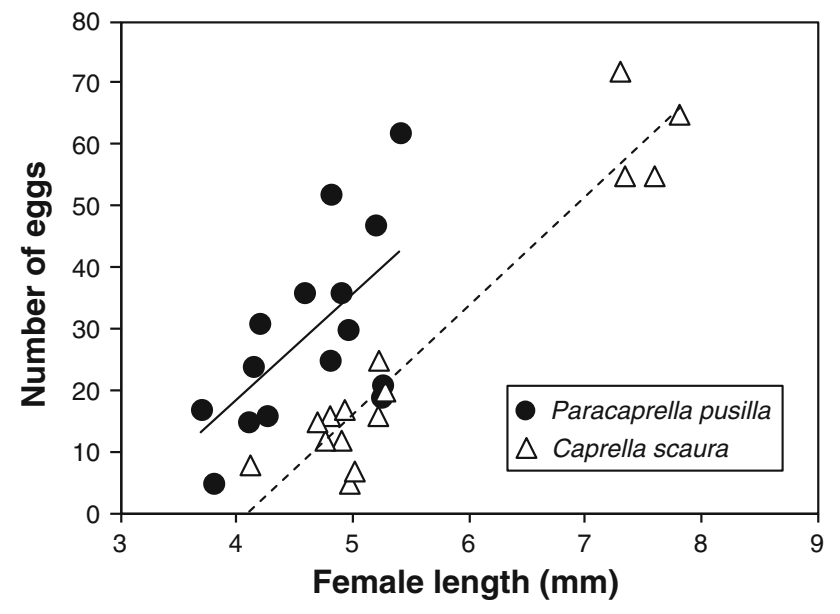

Fig. 4 Correlations between female size and number of eggs per brood in Paracaprella pusilla and Caprella scaura collected at Mallorca

status of Paracaprella pusilla in European waters can be assessed using the criteria of Chapman and Carlton (1994): (1) previously unknown in local region; (2) post-introduction range expansion; (3) associated with a human dispersal mechanism; (4) associated with or dependent on other introduced species; (5) associated with artificial environments; (6) restricted or discontinuous distribution in the region; (7) disjunct global distribution; (8) insufficient life history adaptations for natural global dispersal; and (9) exotic evolutionary origin. Paracaprella pusilla scores positively on criteria $1,2,3,5,6,7,8$ and 9 , suggesting it to be an alien species to the area. As this is the first record of the genus Paracaprella in the Mediterranean Sea, it increases the known diversity of the Caprellidea in this region.

\section{Global distribution of P. pusilla}

According to Mayer (1903), the species' natural area of distribution is the Atlantic coast of Central and South America. Most records of $P$. pusilla are from the Gulf of Mexico and the Caribbean coast (Ros and Guerra-García 2012), and the species is one of the most abundant caprellids along the Caribbean coast of Venezuela and Colombia (Díaz et al. 2005; Guerra-García 2006). Therefore, the species appears to have a strong Caribbean affinity (Carlton and Eldredge 2009). Nevertheless, the origin of Paracaprella pusilla is unknown (Mead et al. 2011). Records on geographically disjunct occurrences of $P$. pusilla date back to the early 1900s, a short time after the species had been described by Mayer in 1890 (see Ros and Guerra-García 2012). This, along with the facts that most of the records refer to fouling communities of harbours, and that the species may be able of travelling long distances attached to vessel hulls, has prevented a clear determination of the origin of the species. Actually, the species' global area of distribution includes the Atlantic coasts of Central and South America, tropical West Africa, East Africa, Hawaii, India, Australia and the southwest coast of Spain.

Introduction pattern of $P$. pusilla to the Mediterranean Sea

Due to a lack of previous studies on caprellids associated with fouling communities in the study area, the exact time of introduction to this site remains unknown for both alien species. However, extensive biological surveys in the Mediterranean over the twentieth century allow for a reasonable measure of confidence in separating alien and native biota (Galil 2009). Never recorded in the Mediterranean waters before, $P$. pusilla is not mentioned neither in the handbook of the Mediterranean amphipods fauna (Ruffo 1993) nor in the study by Guerra-García et al. (2011a, b) on the intertidal and shallow water caprellids of the Iberian Peninsula. Moreover, Caprella scaura and $P$. pusilla were not recorded neither in a study on amphipods of Ibiza (Ballesteros et al. 1987) nor in a more recent study on amphipods of Mallorca (Box 2008). Therefore, the introduction of these caprellids to the European waters of southern Spain and the Western Mediterranean Sea may have occurred during the last decade. The date of the introduction of the inoculum is significant for the study of the patterns and processes of invasion but is extremely difficult to ascertain for unintentional or undocumented intentional introductions (Galil 2011).

There are two main alternatives to explain the presence of $P$. pusilla in the Mediterranean Sea (Fig. 5): The species entered (a) via the Suez Canal (Port Said) on vessels from the Indo-Pacific, or (b) through the Strait of Gibraltar, on vessels arriving from the Atlantic coast of America or from the established population in southwest Spain. The presence of $P$. pusilla in the Suez Canal was only reported by Schellenberg (1928), who recorded the species in three stations: Kantara (46 km from Port Said), Kabret (between Little Bitter Lake and Great Bitter Lake) and Port Taufiq. This seems to support hypothesis (a). However, so far, the species has not been recorded neither in the Red Sea nor along the Mediterranean Sea, and recent studies on the fouling community in the Suez Canal by Emara and Belal (2004), including Little Bitter Lake, Kabret, Great Bitter Lake and Port Taufiq, reported only the presence of the caprellid species Caprella equilibra, which was also the only caprellid species found in the fouling communities of the Suez Canal by El-komi (1998). Probably, the population found by Schellenberg in 1928 did not succeed in adapting fast enough to the new environment and failed in spreading to adjacent areas. Moreover, the absence of 


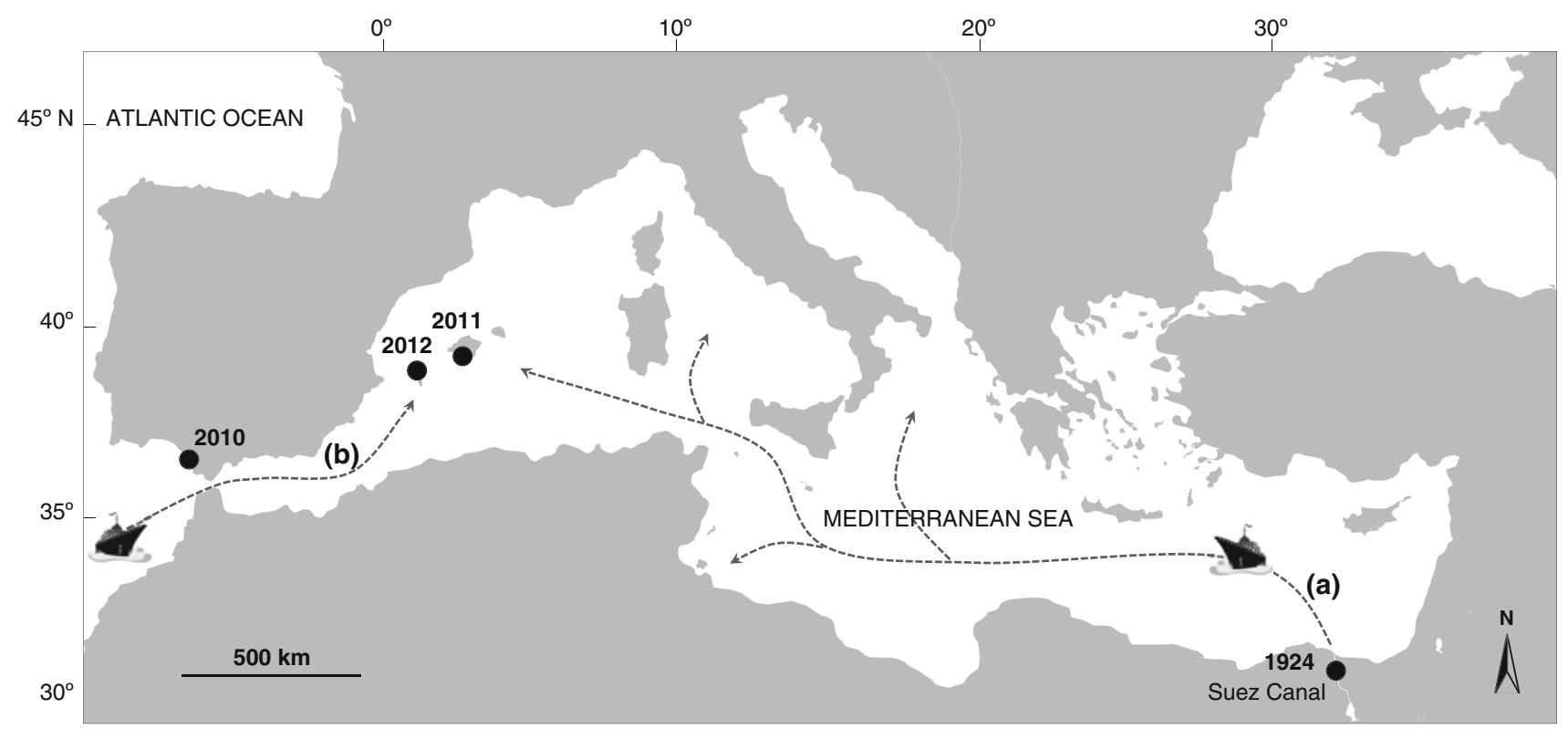

Fig. 5 Distribution map of Paracaprella pusilla in the Mediterranean Sea with years of first record for the different areas. Arrows indicate two possible ways of introduction to the Mediterranean Sea (see text)

$P$. pusilla in the Red Sea and its relatively recent record in the Indian Ocean (Sivaprakasam 1977) suggest that the populations recently found in European coastal waters originate from the Atlantic coasts of Central and South America, where the species is highly abundant. In this case, an introduction through the Strait of Gibraltar (hypothesis b) would be more probable than the alternative (hypothesis a). Interestingly, many small craft of Mallorca overwinter in marinas in the south of Spain (Minchin et al. 2006) and thus could represent a suitable vector for the secondary spread of the species from the established population of southern Spain to the Balearic Islands. Marinas seem to provide a network of suitable habitats for the secondary spread of a species via recreational yachting activity (Ashton et al. 2006).

Unlike what happened when Schellenberg found the species in the Suez Canal in 1928, the last decades of the twentieth century saw pronounced thermal fluctuations and a significant increase in the average seawater-surface temperature in the Mediterranean (Nykjaer 2009). This may favour survival, growth and reproduction of tropical aliens, giving them a distinct advantage over native temperate Mediterranean taxa (Galil 2011). Along with the increasing role of the Mediterranean as a hub of international commercial shipping (Dobler 2002), this might explain the fact that $P$. pusilla has successfully reached the Western Mediterranean Sea only most recently.

The precautionary principle suggests to considering each alien species 'guilty until proven innocent' and calls for analyzing possible impacts on native communities (Occhipinti-Ambrogi et al. 2011). Taking into account that the occurrence of $P$. pusilla in the Mediterranean Sea is probably a consequence of secondary spread from the established population in the Strait of Gibraltar, and that the fraction of alien species that spread following establishment is considered one of the measures of invasion success (Galil 2011), the presence of P. pusilla at the Balearic Islands suggests a future invasion along marinas of the Mediterranean Sea.

Acknowledgments The authors would like to thank Elena BaezaRojano, Carlos Navarro and Elvira Álvarez for their assistance during sampling. We also wish to thank Dr. Salud Deudero for her technical support, and the anonymous reviewers for their suggestions to improve the manuscript. Financial support of this work was provided by a predoctoral grant from the Spanish Government (Reference AP2009-3380), by the Ministerio de Economía y Competitividad (Project CGL2011-707) co-financed by FEDER funds of the European Union and by the Consejería de Economía, Innovación, Ciencia y Empleo, Junta de Andalucía (Project P11-RNM-7041).

\section{References}

Ashton G, Boos K, Shucksmith R, Cook E (2006) Risk assessment of hull fouling as a vector for marine non-natives in Scotland. Aquat Invasions 1(4):214-218

Baeza-Rojano E, Cabezas MP, Pacios I, Guerra-García JM (2011) Life history of Caprella grandimana (Crustacea: Amphipoda) reared in laboratory conditions. Mar Biol Res 7:85-92

Bakir K, Katagan T (2011) On the occurrence of Caprella scaura Templeton, 1836 (Crustacea: Amphipoda) in Turkish waters. Zool Middle East 52:125-126

Ballesteros M, Castelló J, Galles M, Sardà R (1987) Invertebrados alguícolas marinos de las Islas Pitiusas. Consell Insular d'Eivissa i Formentera. Conselleria d'Ecologia i Medi Ambient. Eivissa 
Bellan-Santini D, Ruffo S (1998) Faunistics and Zoogeography. In: Ruffo S (ed) The Amphipoda of the Mediterranean, Part 4. Mémoires de l'Institut Océanographique (Monaco) 13(4):895-911

Box T (2008) Ecología de caulerpales: fauna y biomarcadores. PhD thesis, Universidad de las Islas Baleares, Palma de Mallorca

Carlton JT (1985) Transoceanic and interoceanic dispersal of coastal marine organisms: the biology of ballast water. Oceanogr Mar Biol Ann Rev 23:313-371

Carlton JT, Eldredge LG (2009) Marine Bioinvasions of Hawai'i: the introduced and cryptogenic marine and estuarine animals and plants of the Hawaiian archipelago. Bishop Mus Bull Cult Env Stud 4:1-203

Chapman JW, Carlton JT (1994) A test of criteria for introduced species: the global invasion by the isopod Synidotea laevidorsalis (Meirs 1881). J Crust Biol 11:386-400

Díaz YJ, Guerra-García JM, Martín A (2005) The Caprellidea (Crustacea: Amphipoda) from Venezuela. Org Div Evol 5: 249-251

Dobler JP (2002) Analysis of shipping patterns in the Mediterranean and Black seas. In: CIESM Alien marine organism introduced by ships in the Mediterranean and Black seas. CIESM workshop monographs, Monaco 20:19-28

Drake JM, Lodge DM (2004) Global hot spots of biological invasions: evaluating options for ballast-water management. Proc Royal Soc London B 271:575-580

Eleftheriou A et al (2011) New Mediterranean biodiversity records. Mediterr Mar Sci 12:491-508

El-Komi MM (1998) Spatiotemporal distribution of fouling and plankton composition in the coastal waters of Alexandria, Egyt. J Egyptian German Soc Zool (Invert Zool Parasit) 27(D):183-207

Emara AM, Belal AA (2004) Marine fouling in Suez Canal Egypt. Egypt J Aquat Res 30:189-206

FEAPDT (2011) Federación Española de Asociaciones de Puertos Deportivos y Turísiticos (FEAPDT). Informe anual de puertos deportivos en España 2011. (available online: www.feapdt.es)

Galil BS (2008) Alien species in the Mediterranean Sea-which, when, where, why? Hydrobiologia 606:105-116

Galil BS (2009) Taking stock: inventory of alien species in the Mediterranean Sea. Biol Invasions 11:359-372

Galil BS (2011) The alien crustaceans in the Mediterranean: an historical overview. In: Galil BS, Clark PF, Carlton JT (eds) In the wrong place-alien marine crustaceans: distribution, biology and impacts. Springer, Berlin, pp 377-401

Grabowski M, Bacela EK, Konopacka A (2007) How to be an invasive gammarid (Amphipoda: Gammaroidea)-comparison of life history traits. Hydrobiologia 590:75-84

Guerra-García JM (2006) Caprellids from the caribbean coast of Colombia, with description of three new species and key for species identification. Boletín de Investigaciones Marinas y Costeras 35:149-194

Guerra-García JM, Ganesh T, Jaikumr M, Rama AV (2010) Caprellids (Crustacea: Amphipoda) from India. Helgol Mar Res 64:297-310

Guerra-García JM, Ros M, Dugo-Cota A, Burgos V, Flores-León AM, Baeza-Rojano E, Cabezas MP, Núñez J (2011a) Geographical expansion of the invader Caprella scaura (Crustacea: Amphipoda: Caprellidae) to the East Atlantic coast. Mar Biol 158(11): 2617-2622

Guerra-García JM, Ros M, Gordillo I, Cabezas MP, Baeza-Rojano E, Izquierdo D, Corzo J, Domínguez J, Varona S (2011b) Distribution patterns of intertidal and shallow water caprellids associated with macroalgae along the Iberian Peninsula. Zool Baetica 21:101-129

Krapp T, Lang C, Libertini A, Melzer RR (2006) Caprella scaura Templeton 1836 sensu lato (Amphipoda: Caprellidae) in the Mediterranean. Org Div Evol 6:77-81
Martínez J, Adarraga I (2008) First record of invasive caprellid Caprella scaura Templeton, 1836 sensu lato (Crustacea: Amphipoda: Caprellidae) from the Iberian Peninsula. Aquat Invasions $3: 165-171$

Mayer P (1890) Die Caprelliden des Golfes von Neapel und der angrenzenden Meeres-Abschnitte. Fauna und Flora des Golfes von Neapel 17:1-55

Mayer P (1903) Die Caprellidae der Siboga Expedition. SibogaExped 34:1-160

Mead A, Carlton JT, Griffiths CL, Rius M (2011) Introduced and cryptogenic marine and estuarine species of South Africa. J Nat Hist 45:39-40

Minchin D, Floerl O, Savini D, Occhipinti-Ambrogi A (2006) Small craft and the spread of exotic species. In: Davenport $J$, Davenport JD (eds) The ecology of transportation: managing mobility for the environment. Environt Pollut 10:99-118

Nykjaer L (2009) Mediterranean Sea surface warming 1985-2006. Climate Res 39:11-17

Occhipinti-Ambrogi A et al (2011) Alien species along the Italian coasts: an overview. Biol Invasions 13:215-237

Pereira SG, Lima FP, Queiroz NC, Ribeiro PA, Santos AM (2006) Biogeographic patterns of intertidal macroinvertebrates and their association with macroalgae distribution along the Portuguese coast. Hydrobiologia 555:185-192

Ros M, Guerra-García JM (2012) On the occurrence of the tropical caprellid Paracaprella pusilla Mayer, 1890 (Crustacea: Amphipoda) in Europe. Mediterr Mar Sci 13:134-139

Ros M, Guerra-García JM, González-Macías M, Saavedra A, López$\mathrm{Fe} \mathrm{CM}$ (2013) Influence of fouling communities on the establishment success of alien caprellids (Crustacea: Amphipoda) in Southern Spain. Mar Biol Res 9(3):293-305

Ruffo S (1982) (ed) The Amphipoda of the Mediterranean. Part 1. Gammaridea (Acanthonotozomatidae to Gammaridae). Memoires de L'Institut Oceanographique Monaco 13(1):1-364

Ruffo S (1989) (ed) The Amphipoda of the Mediterranean. Part 2. Gammaridea (Haustoriidae to Lysianassidae). Memoires de L'Institut Oceanographique Monaco 13(2):365-576

Ruffo S (1993) (ed) The Amphipoda of the Mediterranean. Part 3. Gammaridea (Melphidippidae to Talitridae) Ingolphiedillea Caprellidea. Memoires de L'Institut Oceanographique Monaco 13(3):577-813

Ruffo S (1998) (ed) The Amphipoda of the Mediterranean. Part 4. Localities and map. Addenda to parts 1-3. Key to families. Ecology. Faunistics and zoogeography. Bibliography. Index memoires de L'Institut Oceanographique Monaco 13(4):813951

Sacchi CF, Sconfietti R, Occhipinti-Ambrogi A (1998) Changes in the benthic communities of hard and soft bottom at the hydrographic boundaries in the Venice Lagoon. Rapp Comm Int Mer Médit 35(2):582-583

Schellenberg A (1928) Report on the Amphipoda. Zoological results of the Cambridge expedition to Suez Canal, 1924. Trans Zool Soc Lond 22:633-692

Sconfietti R, Mangili F, Savini D, Occhipinti-Ambrogi A (2005) Diffusion of the alien species Caprella scaura Templeton, 1836 (Amphipoda: Caprellidae) in the northern Adriatic Sea. Biol Mar Mediterr 12:335-337

Sivaprakasam TE (1977) The skeleton shrimps (Amphipoda: Caprellidea) of the Tamil Nadu and Kerala coasts. J Mar Biol Ass India 19:78-96

Souissi JBen, Kahri C, Salem MBen, Zaouali J (2010) Les espèces non indigènes du macrobenthos des lagunes du sud-est tunisien: point sur la situation. Rapp Comm Int Mer Médit 39:449

Sturaro N, Guerra-García JM (2011) A new species of Caprella (Crustacea: Amphipoda) from the Mediterranean Sea. Helgol Mar Res 66:33-42 
Takeuchi I, Sawamoto S (1998) Distribution of caprellid amphipods (Crustacea) in the western North Pacific based on the CSK international zooplankton collection. Plankton Biol and Ecol 45:225-230

Templeton R (1836) Descriptions of some undescribed exotic Crustacea. Trans Entomol Soc Lond 1:185-198

Thiel M, Guerra-García JM, Lancellotti DA, Vásquez N (2003) The distribution of littoral caprellids (Crustacea: Amphipoda: Caprellidea) along the Pacific coast of continental Chile. Rev Chil Hist Nat 76:203-218

Weis JS (2010) The role of behavior in the success of invasive crustaceans. Mar Freshw Behav Physiol 43(2):83-98
Willis KJ, Cook EJ, Lozano-Fernandez M, Takeuchi I (2004) First record of the alien caprellid amphipod, Caprella mutica, for the UK. J Mar Biol Ass UK 84:1027-1028

Woods CM (2009) Caprellid amphipods: an overlooked marine finfish aquaculture resource? Aquaculture 289:199-211

Zenetos A et al (2010) Alien species in the Mediterranean Sea by 2010. A contribution to the application of European Union's marine strategy framework directive (MSFD). Part I. Spatial distribution. Med Mar Sci 11(2):381-493 